\title{
Impact of Motivational Strategies on Employee Motivational Level: A Case Study of National Bank of Pakistan in Azad Jammu and Kashmir
}

\author{
Shagufta Ashraf ${ }^{1}$, Ghulam Mustafa Azam ${ }^{1}$, Waqar Ashraf ${ }^{2}$ \\ ${ }^{1}$ Department of Public Administration, Faculty of Administrative Sciences, University of Management Sciences and Information Technology \\ Kotli, Azad Kashmir, Pakistan \\ ${ }^{2}$ Department of Business Administration, Faculty of Administrative Sciences, University of Management Sciences and Information \\ Technology, Kotli Azad Kashmir, Pakistan
}

Email address:

xhagufta@yahoo.com (S. Ashraf), mustafa19867@gmail.com (G. M. Azam), waqar_17hrm@yahoo.com (W. Ashraf)

\section{To cite this article:}

Shagufta Ashraf, Ghulam Mustafa Azam, Waqar Ashraf. Impact of Motivational Strategies on Employee Motivational Level: A Case Study of National Bank of Pakistan in Azad Jammu and Kashmir. Journal of Investment and Management. Vol. 4, No. 5, 2015, pp. $191-195$. doi: $10.11648 /$ j.jim.20150405.18

\begin{abstract}
The study sought to find out the motivational strategies and its impact on employee motivational level. The purpose of the study is to provide effective motivational strategies for banking sector of Azad Kashmir to use to motivate employee's, improve and increase productivity in organization. The Literature review enables us to understand the various theories on motivation and the effects have on productivity. The researcher adopted a questionnaire to collect primary data regarding what will make employees to perform and increase productivity. The study was conducted by collecting data from sample of 90 respondents selected from five districts of Azad Jammu and Kashmir including Mirpur, Kotli, Palandri and Bagh and Rawalakot using questionnaire. The data was analyzed using frequencies and percentage distribution. The result shows that "Advancement Opportunity" has the highest impact on motivational level on employees working in National Bank of Pakistan working in Azad Kashmir.
\end{abstract}

Keywords: Motivation, Human Resource (HR), Strategy, Workforce, Public Sector, Productivity, Intrinsic Motivation, Extrinsic Motivation

\section{Introduction}

\subsection{Background of the Study}

In present business world, motivating people to perform their best has become difficult enough than ever, due to crucial economic uncertainties as well as competition. HR are the only factor that can be helpful for successful organizations (public as well as private) in this turbulent environment. Therefore challenging concern of $\mathrm{HR}$ department is to establish and maintain competent workforce. Motivation is defined as, "An individual's degree of willingness to exert high level of effort to reach organizational goals", (Robin and Decenzo, 1995). Healthy organizations always seek out individuals who are motivated enough to perform well on the work place. In addition they always looking forward for those people who have the ability to motivate others whether they are their subordinates, peers, or superiors to transcend to the limits for the accomplishment of the goals assigned to them and ultimately become transformational leader in future. If the management of organizations can motivates their employee in such a way that they can solve severe problems and can meet customer's expectations, then organizational goals and objectives can be realized, (Havard Press, 2005). If there is a direct relationship between motivation and productivity then worker's motivation is inevitable. High level of motivation can prove a springboard for action. Motivation is the only mean that can attract effective workforce, but as motivation is an interactive process between workers and their work environment. So supportive management and effective supervision are still critical factors in order to reach organizational goals, (Hornby and Sidney, 1988). 


\subsection{Statement of the Problem}

Many researchers have studied employee motivation so far with its length. Main misconception about motivation was good wages as a primary motivational strategy among employees regardless of the organization in which they are employed, (Tsang Wong, 1997). One of the most difficult and important duties for the management is employee motivation so far.

Employee motivation is as complicated process as individuals are complex, diverse and often difficult to predict None of the motivational theories have explained motivation particularly across diverse cultures. The study is therefore aimed at researching the motivational strategies existing in the banking sector limited in particular of Azad Jammu and Kashmir and which one of the strategies have highest impact on employee motivational level.

\subsection{Objectives of the Study}

1. Analyze the importance of motivational strategies on employee motivational level.

2. Identify the motivational strategies which can promote positive motivational behavior among employees.

\subsection{Research Questions}

1. What motivational strategies you can find in public sector banking of AJ\&K?

2. What are the strategies that motivate employees in public sector banking of AJ\&K?

3. What is the impact of motivation on performance of employees of public sector banking of AJ\&K?

\subsection{Significance of the Study}

Current study will help the organization not only to manage but to improve performance of human resources for the achievement of maximum efficiency and effectiveness in the services delivery. The research will also suggest and recommend strategies which can motivate and improve productivity in the public service.

\section{Literature Review}

\subsection{Motivation}

\section{Overview}

As the people are major aspects in the progress of firms in this competitive era. It is most important to earn the employee's commitment and the best possible way to do this is by offering them corporate initiatives.(Mick Marchington and Arden Wilkson, 2008). The employer wants that the employee must have desire to complete the task as the manager's want by going beyond its capacity and limits. Underlying concept of motivation is a source for individuals through which they may attempt to achieve desired goals for the fulfillment of certain needs. (Mullins, 1996). Its an inside feeling or desire to perform or not to perform for attainment of desired needs. The radical principle for management to realize and understand that what is the source of motivation for people so that it may affect work performance, recruitment and retention. Employees should also think that what are their expectations through which they may be happy and satisfied.

\subsection{Definitions}

The word "motivation is derived from the latin word" Movere" means "to move" "Motivation is a psychological process that gives behavior, purpose and direction, (Kreitner, 2001)

"Motivation as those psychological processes that cause arousal, direction and persistence of voluntary actions that are goal directed, (Robert Kreitner and Ageloo Kinicki, 2001). For doing something motive is a basic reason. Motivation is linked with the factors those influence people to behave in certain ways. Following are the three factors Arnold et al identified:

- Direction: What a person is trying to do

- Effort: How hard a person is trying

- Persistence: How long a person keeps on trying, Armstrong, 2006)

\subsection{Sources of Motivation}

\subsubsection{Intrinsic Motivation}

It actually originates from the direct relationship between the worker and the task. It is usually being applied. The examples of intrinsic motivators are feeling of achievement, accomplishment, challenges and competence derived from performing a job.

\subsubsection{Extrinsic Motivation}

It originates from the work environment and usually applied by someone else than the person being motivated. Examples are pay, company policies, fringe benefits and various forms of supervision.

\subsection{Characteristics of Motivation}

Mitchell, 1982 quartered by Mullins,2005 identified four characteristics:

- Motivation is characterized by an individual phenomenon: Every person is unique in nature and all the major theories of motivation allow to be demonstrated in one way or the other.

- Motivation is usually intentional: Motivation is assumed to be under the control of the worker and the behavior that are influenced by motivation such as efforts expended are seen as choices of action.

- Motivation is multifaceted.

- The purpose of motivational theories is to predict behavior. Motivation is not a behavior itself and it is not performance. Motivation concerns actions, internal and external forces, which influence a person's choice of action. 


\subsection{Motivational Theories}

\subsubsection{Instrumentality Theory}

Instrumentality theory argues that if we do one thing it will lead to another. It is of belief that people work for money. It assumes that a person will be only motivated if rewards and penalties are tied directly to his or her performance. Thus the rewards are contingent upon effective performance.

\subsubsection{Content (Needs) Theory of Motivation}

Most of the content theories of motivation hover around the notion that employees influence motivation. Needs are physiological or psychological deficiencies that arouse behavior, may be weaker or stronger and are influenced by certain environmental factors. Thus needs vary over time and place. Abridgement is not fulfillment of desired needs motivate people to satisfy them.

- Content (Needs) theory Motivation includes:

a. Maslow's need hierarchy theory

b. Herbergz two factors theory

- Process theory (Cognitive Theory)

a. Expectancy Theory

b. Goal Theory

c. Equity Theory

- A non cognitive theory of motivation: Reinforcement Theory

\subsection{Motivation Strategy}

The aim of the motivation strategy should increase the effective contribution of employee of any organization in order to achieve its desired objective. Motivation strategy will refer to performance of the financial incentive based management and reward systems.
But also be related to the other processes yielding positive attitudes towards participation in job design, setting objectives jointly, development of career and other processes pertaining to the individual need of achieving and maintaining a sense of being wealthy and important. The quality of leadership in an organization also effects motivation hence selecting, training and developing effective leaders should be included in the strategy (Armstrong, 2006).

\subsection{Public Service Motivation}

In public management, empirical research about public service management has increased over the years as matter of facts: It is one of the fundamental concepts of human resource management in the public sector (Coursey and Pandey 2007a). Public Service Motivation was initially defined as "The individual predisposition to respond to motives grounded primarily or uniquely in public organizations or institutions", (Perry and Wise 1990). Public Service Motivation represents "Beliefs, values and attitudes that goes beyond self interest and organizational interest that concerns the interest of a larger political entity and that motivates individual to act accordingly whenever appropriate, (Vandenabeele, 2007a, 54). According to Public Service Motivation perspective the motivation of public employees oriented towards the realization of values and goals of public service through an identification process. Values and goals of public service are part of self definition of certain public employees and determine the justification of their behavior. Surprisingly few studies have tested the assumption that public service motivation has an impact on work motivation. Taylor's study is also a dimensional analysis of public service motivation in relation to work outcomes, (Taylor, 2007).

Table 1. Motivation Strategy.

\begin{tabular}{|c|c|}
\hline Factors affecting motivation strategies & The HR contribution \\
\hline $\begin{array}{l}\text { The complexity of the process of motivation means that } \\
\text { simplistic approaches based on instrumentality theory are } \\
\text { unlikely to be successful }\end{array}$ & $\begin{array}{l}\text { Avoid the trap of developing or supporting strategies that offer prescriptions for } \\
\text { motivation based on a simplistic view of the process or fail to recognize individual } \\
\text { differences }\end{array}$ \\
\hline $\begin{array}{l}\text { People are more likely to be motivated if they work in an } \\
\text { environment in which they are valued for what they are and what } \\
\text { they do. This means paying attention to the basic need for } \\
\text { recognition }\end{array}$ & $\begin{array}{l}\text { Encourage the development of performance management process which provide } \\
\text { opportunities to agree expectations and give positive feedback an accomplishments } \\
\text { Develop reward systems which provide opportunities for both financial and non- } \\
\text { financial rewards to recognize achievements. Bear in mind, however, that financial } \\
\text { rewards system are not necessarily appropriate and the lessons of expectancy, goal and } \\
\text { equity theory need to be taken into account in designing and operating them }\end{array}$ \\
\hline $\begin{array}{l}\text { The need for work which provides people with the means to } \\
\text { achieve their goals, a reasonable degree of autonomy, and scope } \\
\text { for the use of skills and competencies should be recognized }\end{array}$ & $\begin{array}{l}\text { Advise on processes for the design of jobs wh } \\
\text { the motivation to work, providing for job enri } \\
\text { making responsibility and as much control as } \mathrm{p}\end{array}$ \\
\hline $\begin{array}{l}\text { The need for the opportunities to grow by developing abilities } \\
\text { and careers }\end{array}$ & $\begin{array}{l}\text { Provide facilities and opportunities for learning through such means as personal } \\
\text { development planning processes as well as more formal training } \\
\text { Develop career planning processes }\end{array}$ \\
\hline $\begin{array}{l}\text { The cultural environment of the organization in the shape of its } \\
\text { values and norms will influence the impact of any attempts to } \\
\text { motivate people by direct and indirect means }\end{array}$ & $\begin{array}{l}\text { Advise on the development of a culture which supports process of valuing and } \\
\text { rewarding employees }\end{array}$ \\
\hline Motivation will be enhanced by leadership which sets the & Devise competency frameworks which focus on leadership qualitie \\
\hline $\begin{array}{l}\text { direction, encourages and simulates achievement, an provide } \\
\text { support to employees in their efforts to reach goals and improve }\end{array}$ & Ensure that leadership potential is identified through performances management and \\
\hline their performance generally & Provide guidance and training to develop leadership qualities. \\
\hline
\end{tabular}




\section{Research Methodology}

This section discusses the methods employed for the study. It involves the description of the population and the sample size, the instruments used for the collection of data, the administration of the instrument and the limitations of the study. Population studied included staff and management of National Bank of Pakistan (Branches of five districts of AJ\&K). Sample size of 90 was selected using the stratified sampling method. The choice of this sampling procedure was, because it has no personal bias and it is scientific and objective. Under this method, the researcher categorized the staff of all branches of National Bank of Pakistan working in Azad Jammu and Kashmir according to their already existing departments namely (Human Resource, Operations, Marketing). The raw data from the field survey was entered into SPSS and the results and its analysis are presented in the data analysis session of this work. The instrument researcher used for the collection of data from the respondents was a questionnaire. Two sets of questionnaire were prepared comprised of close-ended questions and open ended questions.60 copies of questionnaire were distributed to general staff and set of 30 questionnaires were administered to management.

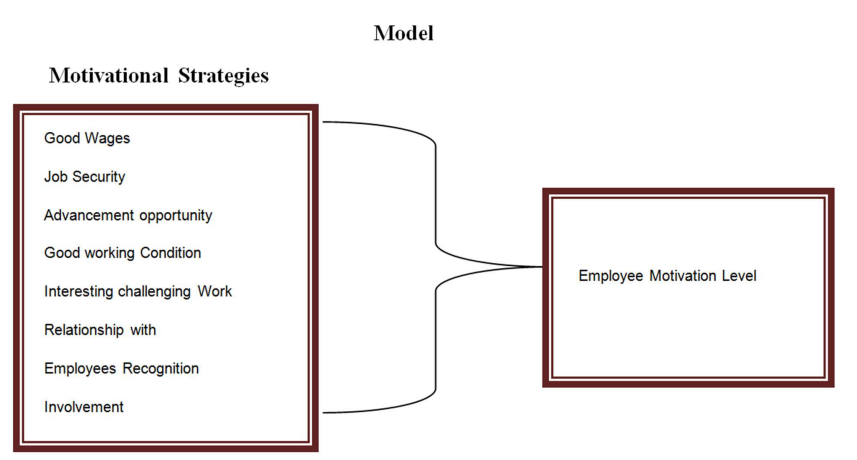

\section{Data Analysis and Discussion of Results}

The background characteristics covered age, sex, and academic qualification for respondents.

Table 2. Descriptive Statistics.

\begin{tabular}{llll}
\hline Age & & Frequency & Percent \\
\hline \multirow{4}{*}{ Valid } & $20-30$ & 42 & 46.7 \\
& $31-40$ & 32 & 35.6 \\
& 50 and above & 16 & 17.8 \\
& Total & 90 & 100.0 \\
\hline
\end{tabular}

Source: Field data 2014

Table 2 reveals that the greater number of personnel (46\%) who answered the questionnaires were employees in the 20-
30 years group. As depicted, also the lowest age profile is 50 years and this group with the representation is only $17.8 \%$. It implies that majority of National Bank of Pakistan in Azad Kashmir's workforce is young and vibrant.

Table 3. Gender Statistics.

\begin{tabular}{llll}
\hline Gender & & Frequency & Percent \\
\hline \multirow{4}{*}{ Valid } & male & 61 & 67.8 \\
& female & 29 & 32.2 \\
& Total & 90 & 100.0 \\
\hline
\end{tabular}

Table 3 reveals that out of 90 respondents, 61 representing $67.8 \%$ were males while 29 representing $32.2 \%$ were females. The difference is not too bad but not encouraging enough. However, the research is not based on any one particular gender but it has been generalized to give a more specific depiction on the impact of motivational strategies on employee motivational level in order to increase employee efficiency at work.

Table 4. Experience of Sample.

\begin{tabular}{llll}
\hline Experience & & Frequency & Percent \\
\hline \multirow{4}{*}{ Valid } & $0-5$ & 24 & 26.7 \\
& $6-10$ & 36 & 40.0 \\
& $11-20$ & 21 & 23.3 \\
& $21-30$ & 9 & 10.0 \\
& Total & 90 & 100.0 \\
\hline
\end{tabular}

Source: Field data 2014

Table 5. Education Statistics.

\begin{tabular}{llll}
\hline Education & & Frequency & Percent \\
\hline & BA & 28 & 31.1 \\
\multirow{4}{*}{ Valid } & Diploma & 12 & 13.3 \\
& MA & 46 & 51.1 \\
& Mphil-PhD & 4 & 4.4 \\
& Total & 90 & 100.0 \\
\hline
\end{tabular}

Source: Field Data 2014

Table 6. Descriptive Statistics.

\begin{tabular}{|c|c|c|c|c|c|}
\hline Variable & $\mathbf{N}$ & Minimum & Maximum & Mean & $\begin{array}{l}\text { Std. } \\
\text { Deviation }\end{array}$ \\
\hline Good Wages & 90 & 3 & 5 & 4.02 & .618 \\
\hline Job Security & 90 & 3 & 5 & 3.98 & .618 \\
\hline $\begin{array}{l}\text { Advancement } \\
\text { opportunity }\end{array}$ & 90 & 3 & 5 & 4.22 & .632 \\
\hline $\begin{array}{l}\text { Good working } \\
\text { Condition }\end{array}$ & 90 & 2 & 4 & 3.27 & .493 \\
\hline $\begin{array}{l}\text { Interesting } \\
\text { challenging } \\
\text { Work }\end{array}$ & 90 & 2 & 4 & 2.82 & .712 \\
\hline $\begin{array}{l}\text { Relationship } \\
\text { with Employees }\end{array}$ & 90 & 3 & 5 & 3.98 & .580 \\
\hline Recognition & 90 & 2 & 4 & 2.91 & .554 \\
\hline Involvement & 90 & 3 & 5 & 4.04 & .634 \\
\hline $\begin{array}{l}\text { Motivation } \\
\text { Level }\end{array}$ & 90 & 3 & 5 & 4.36 & .679 \\
\hline
\end{tabular}


Table 4 reveals the number of years the respondents have been working with the organization. Further shows that $26 \%$ staff have been with organization from $0-5$ years, $40 \%$ between 6-10 years, 23\% between 11-20 years and 10\% between 21-30 years. None of the staff worked above 30 years. The staff who worked for the organization between 610 years formed the majority.

Table 5 explains that respondents sampled were mainly degree holders. Other professionals were $13.3 \%$ were diploma holders $31.1 \%$ were B.A, $51.1 \%$ were MA,4.4\% were M.Phil $/ \mathrm{PhD}$. According to these figures employees are mostly highly educated. It is encouraging that most of the employees were attaining higher studies, which can go a long way to strengthen the National Bank of Pakistan.

Above table describe the average values of respondents against the five point lickert scale $(1=$ very low and $5=$ very high). The mean of "Good Wages" is 4.02 that reveals respondents believe good wages have more than high impact on their motivation level. Mean of "Job Security"3.98 reveals that respondents believe job security have more than average impact on their motivational level. Mean of "Advancement opportunity"4.22 shows that respondents believes that advancement opportunities have more than high impact on their motivational level, which has highest impact on employee motivational level means that employee of National Bank Believes that advancement opportunity is the most impactful strategy. Whereas mean of "Good Working Conditions" is 3.27 shows that respondents believe that good working conditions have more than average impact on their motivational level. Mean of interesting challenging work is 2.82 shows that respondents believe that interesting challenging work has less than average impact on their motivational level means that they don't believe that interesting challenging work has much impact on their motivational level. Mean of "Relationship with Employees" is 3.98 reveals that respondents believe that relationship with Employees have more than average impact on their motivational level. Mean of "Recognition" is 2.91 reveals that respondents believe that recognition has less than average impact on their motivational level. Mean of "Involvement" is 4.04 shows that respondents believe that involvement have more than average impact on their motivational level. The mean of "Motivation Level" is 4.36 that shows the average impact of organizational motivational strategies have more than high impact on motivation level.

\section{Conclusion}

The results of the study shows that employees believe that the organizational strategies i.e good wages, job security, advancement opportunity, good working conditions, interesting challenging work, relationship with employees, recognition, involvement have positive impact on their motivational level. Results shows that "Advancement Opportunity" have very high impact among the variables of motivational strategies. According to the employees of
National Bank of Pakistan working in Azad Kashmir Advance opportunity is the only variable through which highest employee' motivational level can be achieved. Whereas involvement is second, good wages third, job security and relationship with employees fourth, good working conditions fifth. Whereas interesting challenging work and recognition have below than average impact on employee motivational level.

\section{Recommendations}

1. National Bank of Pakistan working in Azad Kashmir should more emphasize on providing "Advance Opportunity" to its employees to increase motivational level in order to enhance performance of employees and ultimately high productivity.

2. National Bank of Pakistan should revisit its motivational strategies keeping in view the results.

\section{References}

[1] Armstrong M., (2006) Human Resource Management Practice, Kogan Page, Pp 251-269

[2] Bloisi W. et. al. (2003), Management and Organizational Behavior, McGraw-Hill, Pp 16208

[3] Benabou R and Triole, J (2003); Intrinsic and Extrinsic Motivation, Review of Economic Studies.

[4] Bratt. R and Triole, J (2003); Intrinsic and Extrinsic Motivation, Review of Economic Studies

[5] Delfqaauw, J. and Dur, R. (2008); Incentives and Workers motivation in the public sector.

[6] Harvard Business School Press (2005), Motivating people for Improved Performance.

[7] Ivananceich, John M. (2004) Human resource management 9th Edition.

[8] Kovach, K. (1987). What motivates employees? Workers and Supervisors give different answers. Business Horizons. September/October, 58-65

[9] Krietner R. et. al.(1999), Organisational behavior, First European edition, McGraw-Hill International Gaming and Wagering Business 15 (3), 17-18.

[10] Marchington M and Wilkinson A. (2005), Human Resource Management at Work: People Management and Development.

[11] Perry J. L and Wise L. R (1990); The motivational Bases of public service

[12] Vandenabeele W (2007); Toward a public Administration theory of public service motivation: An institutional Approach, Public Management Review.

[13] Taylor, S. L., Cosenza, R. (1997). 10 thoughts on employee retention.Human Resource Focus 74 (10). 74

[14] Werner J. M and Desimone R. L (2006), Human Resource Development. 